\section{Diversity Management in the Czech Republic as an Answer to Demographic Changes}

\author{
Elwira Gross-Gołacka \\ Alcide De Gasperi University of Euroregional Economy in Józefórw, Poland \\ elwira.gross-golacka@wp.pl \\ Jana Marková \\ College of International and Public Relations Prague, Czech Republic \\ janamarkova1@gmail.com \\ Jan Slavicek \\ The Institute of History of the Czech Academy of Sciences, \\ Department of the 20th Century History \\ jan_slavicek@yahoo.cz
}

\begin{abstract}
Purpose - The main objective of the following article is to present issues associated with managing diversity in the context of demographic changes. The aim of this paper is to offer concrete suggestions on how organizations can overcome demographic changes and tap the business potential of diversity management.

Design/Methodology/Approach - The authors' approach is based on the literature, statistic data and authors' own research. The empirical part was developed on the basis of survey research titled "Diversity Management in the V4 Countries as an Answer to Demographic Changes". The research was quantitative, implemented through the computer-assisted personal interviewing (CAPI) technique on a group of 101 respondents. The research study was conducted in 20162017.

Findings - According to the research, knowledge and practice of diversity management is not very widespread in the Czech Republic. The research has shown that according to the opinion of the respondents from organisations, they recognize differences in motivation factors for specific groups of employees. The majority of respondents see the values and benefits of different groups of employees, as well as their specific needs. The majority of respondents know that specific groups can be the objects of various types of discrimination.

Practical implications - Changes taking place on the labour market and globalization - and in particular the demographic changes in the Czech Republic - have evoked a necessity of searching for new strategies of management. Contemporary human resources management strategies should take into account social and demographic changes and the influence of those changes on customer purchase behaviour and requirement. Therefore, knowledge of diversity management and practical applications should be reflected in strategies of organizations. Results of the study
\end{abstract}

\author{
Diversity \\ Management \\ in the Czech \\ Republic as an \\ Answer to \\ Demographic \\ Changes
}


IJSR

6

provide general guidelines for determining the direction of how important diversity management should be in organizations.

Originality/value - The research concerns diversity management in the Czech Republic with respect to demographic changes.

Keywords - diversity management, the Czech Republic, implementation, demographic changes

\section{Introduction}

As a result of globalization, labour market changes, changes in society, or demographic development, diversity management has become ever more important for the whole society and business. Demographic changes will have a key impact on the labour market over the next two decades (and later), both in Poland and in the rest of Europe. The demographic trends presented above will have serious consequences for organisations and managers in the decades to come. Implications include: the need for a better understanding and awareness of different social groups and appreciating how diversity can bring benefits for organisations. Although this does require flexibility at work, while ensuring quality work through creating non-discriminating environments inside organisations and a better integration between life-work balance. Hence, organisations are increasingly characterised by diversity, both in terms of their external and internal surroundings. Maximising and tapping into diversity in the workplace is an important issue for the quality of managing human resources (and not only) today (Gross-Gołacka, 2016, p. 28). It is interesting to look at the awareness of managers of the issues of diversity management and demographic changes, as they are important for the future of management and development. Therefore, this article is concerned with this awareness and the opinions pertaining to diversity management of Czech managers/owners.

\section{Terminological Findings}

Classically (see e.g. Mor Barak, 2011, pp. 136-145; Thomas, 1999; Thomas, 1991; Loden, Rosener, 1991), diversity has been defined as a mosaic of characteristics brought to the organisation by employees; characteristics such as gender, age, race, ethnicity, religion, family conditions or physical abilities. Diversity among employees can also be concerned with the diversity of functions in a given organisation. It also includes lifestyle, sexual preferences, origin, work experience at an organisation, the status of being dismissed or employed. Diversity, in its broad definition, can relate to any perceived difference and similarity between people, both observable and otherwise (the effect will be a wide and universal approach). Diversity is understood as a collection of characteristics, including all characteristics differentiating one person from another (in terms of employees) and their similarities.

The term "diversity management" has been used for the first time in the United States in the 1980s, but only in the 1990s did the concept find its reflection in the activities undertaken by organisations. It has to be noted that while the concept has developed based on historical developments, it is also strongly rooted in practice (Gross-Gołacka, 2018, p. 11). 
Diversity management is a wide and complex term, and, therefore, it seems that it is difficult to set a single standard or system encompassing all aspects associated with the issue (Rakowska, 2014, pp. 351-360). Authors of multiple publications define the field and its components in different ways. An overview of them allows one to observe that diversity management is an interdisciplinary category, which utilises several perspectives, namely economic, social and biological ones.

Özbilgin and Tatli (2008) define diversity management as a management philosophy, meaning that diversity in organisations is recognised and valued, and that the goal is to increase the performance of the organisation. Egan and Bendick (2008, pp. 387-393) define diversity management as a "systematic and planned creation of programmes and procedures, aimed at improving the interaction between different (based on ethnic origin, gender and culture) employees in order to make diversity a source of creativity, complementarity and higher effectiveness of an organisation (...)".Generally speaking, diversity management regards utilising all available talents in an organisation, without referring to ethnocentrism and stereotypes. It pertains to a group of employees: conducting policy on behalf of diversity, while contributing to an increase of innovativeness and creative activities, reducing any lacks of human resources with specified abilities and improving the quality of service for clients. It is introduced through strategic management oriented towards adapting the organisation to its environment. Diversity management is made up by all activities of an organisation, which are aimed at including optimal utilisation of diversity in the workplace.

In the Czech Republic, diversity management has gradually become a topic and important issue in the field of development and use of human resources, namely after the Czech Republic joined the European Union (Elexowa, 2011; Eger, 2012).

\section{Demographic situation in the Czech Republic}

Within the theme of diversity management, it worth discussing the demographic situation in the Czech Republic. The demographic situation will be described based on the population change and age structure; net migration as the main driver of population growth; and implications of demographic change on employment growth.

\section{Population change and age structure}

Population is growing very slowly. There are 10579 thousand persons in the Czech Republic - 5201 thousand men and 5378 thousand women in the year 2016. There are 1647 thousand persons at the age of $0-14$ in the Czech Republic, this number of children has been growing very slowly since 2011 . The number of children had been declining from 2253 thousand in 1989. The number of persons at the age of 15-64 has been still declining since 2007. However, the number of seniors at the age 65 and more is stable growing. The percentage of seniors has been bigger than the percentage of juniors since 2007. The data has been presented in Table 1 .

\author{
Diversity \\ Management \\ in the Czech \\ Republic as an \\ Answer to \\ Demographic \\ Changes
}


Pobrane z czasopisma International Journal of Synergy and Research http://ijsr.journals.umcs.pl Data: 26/04/2023 15:50:41

IJSR

6

Table 1.

Population

Table 2.

Migration in

the Czech Republic

\begin{tabular}{lccccccccc}
\hline & 1989 & 1991 & 1999 & $\mathbf{2 0 0 3}$ & $\mathbf{2 0 0 7}$ & $\mathbf{2 0 1 1}$ & $\mathbf{2 0 1 4}$ & $\mathbf{2 0 1 5}$ & $\mathbf{2 0 1 6}$ \\
\hline $\begin{array}{l}\text { Population } \\
\text { (thousands) }\end{array}$ & 10362 & 10313 & 10278 & 10211 & 10381 & 10505 & 10538 & 10554 & 10579 \\
\hline Men & 5036 & 5006 & 5001 & 4975 & 5083 & 5158 & 5177 & 5186 & 5201 \\
\hline Women & 5326 & 5307 & 5277 & 5237 & 5298 & 5347 & 5361 & 5368 & 5378 \\
\hline At the age of: & & & & & & & & & \\
\hline $0-14$ & 2253 & 2121 & 1707 & 1554 & 1477 & 1541 & 1601 & 1624 & 1647 \\
\hline $15-64$ & 6817 & 6877 & 7153 & 7234 & 7391 & 7263 & 7057 & 6998 & 6943 \\
\hline 65 and more & 1292 & 1315 & 1418 & 1423 & 1513 & 1701 & 1880 & 1932 & 1989 \\
\hline At the age of (in \%): & & & & & & & & & \\
\hline $0-14$ & 21.7 & 20.6 & 16.6 & 15.2 & 14.2 & 14.7 & 15.2 & 15.4 & 15.6 \\
\hline $15-64$ & 65.8 & 66.7 & 69.6 & 70.8 & 71.2 & 69.1 & 67.0 & 66.3 & 65.6 \\
\hline 65 and more & 12.5 & 12.8 & 13.8 & 13.9 & 14.6 & 16.2 & 17.8 & 18.3 & 18.8 \\
\hline
\end{tabular}

Source: www.czso.cz

\section{Net migration as the main driver of population growth}

A faster growing population is filled by net migration which is stable - in 2016 it was 20064 persons. This means 1.9 immigrants per 1000 inhabitants. The data has been presented in Table 2 .

\begin{tabular}{|c|c|c|c|c|c|c|c|c|c|}
\hline & 1989 & 1991 & 1999 & 2003 & 2007 & 2011 & 2014 & 2015 & 2016 \\
\hline Immigrants & 9400 & 14096 & 9910 & 60015 & 104445 & 22590 & 41625 & 34922 & 37503 \\
\hline Emigrants & 7941 & 11220 & 1136 & 34226 & 20500 & 5701 & 19964 & 18945 & 17439 \\
\hline Net migration & 1459 & 2876 & 8774 & 25789 & 83945 & 16889 & 21661 & 15977 & 20064 \\
\hline $\begin{array}{l}\text { Increase by migration } \\
\text { to } 1000 \text { inhabitants }\end{array}$ & 0.1 & 0.3 & 0.9 & 2.5 & 8.1 & 1.6 & 2.1 & 1.5 & 1.9 \\
\hline Natural change & 609 & 5064 & -20297 & -17603 & 9996 & 1825 & 4195 & -409 & 4913 \\
\hline $\begin{array}{l}\text { Natural change } \\
\text { to } 1000 \text { inhabitants }\end{array}$ & 0.1 & 0.5 & -2.0 & -1.7 & 1.0 & 0.2 & 0.4 & -0.0 & 0.5 \\
\hline Total change & 2068 & 7940 & -11523 & 8186 & 93941 & 18714 & 25856 & 15568 & 24977 \\
\hline $\begin{array}{l}\text { Total change } \\
\text { to } 1000 \text { inhabitants }\end{array}$ & 0.2 & 0.8 & -1.1 & 0.8 & 9.1 & 1.8 & 2.5 & 1.5 & 2.4 \\
\hline
\end{tabular}

Source: www.czso.cz

In comparison to V4 countries, the migration is biggest in Poland (about 218000 persons) and lowest in Slovakia (about 7000 persons). In the last ten years, the total immigration has fluctuated due to various reasons. The highest level of immigration was observed in 2007. The number of immigrants to Slovakia is stable. The number of 
immigrants in Poland has grown nearly twenty times over the last ten years. The data has been presented in Table 3 .

When it comes to citizenship, there is about one quarter of immigrants from Ukraine, one fifth of immigrants from Slovakia, and more than $10 \%$ of immigrants from Vietnam (European Commission, 2015). The data has been presented in Table 4.

The accession of the Czech Republic to the European Union in 2004 (alongside 9 other countries) gave rise to a large wave of labour migration from these countries to the EU15 states, in particular those that were first to open their labour markets to "new" EU citizens (especially to the United Kingdom) (Anrdovicova et al., 2017).

The Czech Republic is a region with intense intraregional migration, accompanied by a significantly lower inflow of immigrants from outside the region. This has been presented in Table 3. In the last decade of the $20^{\text {th }}$ century, thousands of Bulgarians, Romanians and Ukrainians started to migrate in search of income to the Czech Republic and other countries in CEE. Initially, dominant among them were petty traders and irregular workers engaged in unskilled jobs. They were later joined by contract workers and entrepreneurs, including migrants from China and Vietnam.

The persistent high level of emigration in the Czech Republic and CEE countries relates to demographic changes (connected with the decline in fertility rates and increasing life expectancy) which lead to the permanent decline in and ageing of native population in this region as shown in Table 1. On the other hand, modernisation, economic development and increasing labour market segmentation will lead to an inflow of immigrants. As it can be predicted, the demand for labour in certain states will result in a new immigration status of these countries.

\begin{tabular}{|c|c|c|c|c|c|c|c|c|}
\hline GEO/TIME & 2006 & 2007 & 2010 & 2011 & 2012 & 2013 & 2014 & 2015 \\
\hline Czech Republic & 68183 & 104445 & 48317 & 27114 & 34337 & 30124 & 29897 & 29602 \\
\hline Hungary & 25732 & 24361 & 25519 & 28018 & 33702 & 38968 & 54581 & 58344 \\
\hline Poland & 10802 & 14995 & 155131 & 157059 & 217546 & 220311 & 222275 & 218147 \\
\hline Slovakia & 5589 & 8624 & 5272 & 4829 & 5419 & 5149 & 5357 & 6997 \\
\hline
\end{tabular}

Source: http://ec.europa.eu/eurostat/; Product code: migr_imm1ctz

\begin{tabular}{lcclcc}
\hline \multicolumn{1}{c}{ Citizens of } & Thousands & $\%$ & \multicolumn{1}{c}{ Born in } & Thousands & $\%$ \\
\hline Ukraine & 102.1 & 23.5 & Ukraine & 94.2 & 23.8 \\
\hline Slovakia & 91.0 & 20.9 & Slovakia & 84.7 & 21.4 \\
\hline Vietnam & 57.6 & 13.3 & Vietnam & 45.9 & 11.6 \\
\hline Russia & 31.7 & 7.3 & Russia & 30.6 & 7.7 \\
\hline Poland & 19.5 & 4.5 & Poland & 18.6 & 4.7 \\
\hline Other & 132.6 & 30.5 & Other & 122.1 & 30.8 \\
\hline
\end{tabular}

Source: European Commission, Demography Report - 2015 edition, http://ec.europa.eu/eurostat

\section{Diversity \\ Management in the Czech \\ Republic as an \\ Answer to \\ Demographic \\ Changes}

Table 3.

Immigration
Table 4.

Main countries of citizenship and birth of the foreign/foreign-

born population, 1 January 2014 


\section{IJSR}

6

\section{Table 5.}

Unemployment rate in the Czech Republic (in $\%$ )
Table 6.

Employment in the Czech Republic

\section{Impact of demographic change on employment growth}

We can also discuss the potential impact of demographic changes on employment growth. In 2016, the unemployment rate in the Czech Republic was very low and slightly lower in 2017 (Marková, 2017). The number of active population is growing very slowly mainly due to the number of immigrants. The unemployment rate is lower than $5 \%$ which is natural unemployment. Unemployment is even lower than $3 \%$ for data, which are using the total population for calculation. The highest unemployment rate was during the crisis in 2010. The data has been presented in Table 5.

\begin{tabular}{lcccccccccc}
\hline \multicolumn{1}{c}{ Year } & $\mathbf{2 0 0 7}$ & $\mathbf{2 0 0 8}$ & $\mathbf{2 0 0 9}$ & $\mathbf{2 0 1 0}$ & $\mathbf{2 0 1 1}$ & $\mathbf{2 0 1 2}$ & $\mathbf{2 0 1 3}$ & $\mathbf{2 0 1 4}$ & $\mathbf{2 0 1 5}$ & $\mathbf{2 0 1 6}$ \\
\hline Thousands & 276 & 230 & 352 & 384 & 351 & 367 & 370 & 324 & 268 & 212 \\
\hline \% of total population & 3.4 & 2.8 & 4.2 & 4.6 & 4.2 & 4.4 & 4.5 & 3.9 & 3.3 & 2.6 \\
\hline \% of active population & 5.3 & 4.4 & 6.7 & 7.3 & 6.7 & 7.0 & 7.0 & 6.1 & 5.1 & 4.0 \\
\hline
\end{tabular}

Source: http://ec.europa.eu/eurostat

The total employment rate for the year 2016 is higher than the goal of the Europe 2020 Strategy at $76.7 \%$. The level of employment has been steadily growing since the end of economic crisis. The data has been presented in Table 6 .

\begin{tabular}{llcccccccccc}
\hline & 2007 & 2008 & $\mathbf{2 0 0 9}$ & $\mathbf{2 0 1 0}$ & $\mathbf{2 0 1 1}$ & $\mathbf{2 0 1 2}$ & $\mathbf{2 0 1 3}$ & $\mathbf{2 0 1 4}$ & $\mathbf{2 0 1 5}$ & $\mathbf{2 0 1 6}$ \\
\hline AGE: 15 to 64 & $\begin{array}{l}\text { Active population } \\
\text { Thousands }\end{array}$ & 5132 & 5163 & 5209 & 5192 & 5146 & 5175 & 5213 & 5206 & 5201 & 5226 \\
\hline Employment & $\%$ of population & 72 & 72.4 & 70.9 & 70.4 & 70.9 & 71.5 & 72.5 & 73.5 & 74.8 & 76.7 \\
\hline
\end{tabular}

Source: http://ec.europa.eu/eurostat

There have been many changes on the Czech labour market after accession to the EU. The free movement of persons in the European Union was important in improving the labour market. However, the issue of unemployment is not crucial in the Czech Republic. The Europe 2020 Strategy is preparing active labour market policies every semester. The main goal of active labour market policies is to increase the employment opportunities for jobseekers and to improve matching between jobs and workers. Unemployment, and especially long-term unemployment, can have serious adverse consequences for the individual, society and the economic system. The Commission is guiding members to design features that help to maximise the benefits of employment incentives. This includes targeting unemployed people who have limited chances for employment, ensuring that the subsidised period increases the productivity of the worker, as well as introducing conditions to increase the probability that the employment relationship will be extended beyond the subsidised period. What is more, regular monitoring and assessment of subsidised firms (and their hiring behaviour) and beneficiary workers is also of importance (European Commission, 2017). 


\section{Objectives of the publication and research methodology}

The aim of this article is to offer concrete suggestions on how organizations can overcome demographic changes and tap into the business potential of diversity management. In order to draw more attention to this issue, the following research questions should be answered:

1. What is the structure of the workforce and what are the forecasts for it in the Czech Republic?

2. How widely-spread is the concept (including its benefits) of diversity management in organizations in the Czech Republic?

3. Do (and if so - how) organizations in the Czech Republic see the role and the needs of diverse human resources in organizations?

4. Is there a need for diversity management in organisations in the Czech Republic taking into account internal (within the companies) and external (the demographic developments in V4 countries) demographic changes?

The following research was a part of the international project entitled "Diversity Management in the V4 Countries as an Answer to Demographic Changes", and has been carried out in the years 2016-2017. Researchers have used both qualitative and quantitative research methods. The questionnaire contained both closed and open questions, and consisted of the following two parts:

- The concept of diversity management (5 questions),

- Changes in the labour force (15 questions).

The questionnaire was designed so that the respondents were able to select answers out of the proposed or indicate their own proposals. Descriptive statistics were utilised in order to obtain answers. Overall, 101 managers and owners of Czech companies partook in the study voluntarily and anonymously (and they came from not only private, but also state-owned enterprises and NGOs). As such, the interpretation of the results of the questionnaire is the topic of the following article. Its purpose is to provide data necessary to analyse the policies of companies regarding diversity management, in order to compare these policies in connection with demographic and social-economic trends.

The research sample consisted of $54(53.47 \%)$ men and 47 (46.53\%) women'. In terms of age, the largest group were people between $40-49$ years of age (32.67\%), followed by the age group between 30-39 (27.72\%) and 50-59 (20.79\%). Managers above 40 years of age (who could be perceived as being more experienced) made up almost $60 \%$ of the respondents (see: Graph 2). ${ }^{2}$

\footnotetext{
1 The number of women could be quite surprising, considering the fact, that the share of women in top management in the Czech Republic (executive directors, members of board of directors, members of supervisory board) is about $5-20 \%$. The explanation is that: 1 . Not only (and generally not) top management of large companies answered the questionnaire; and 2. More than $37 \%$ of respondents were HR specialists, who - in the Czech Republic - are mostly women. See: The Share of Women in Top Management. Deloitte Corporate Governance Centrum, 2014, https://www2.deloitte.com/cz/cs/pages/about-deloitte/ articles/cze-zeny-ve-vedeni-firem-zdravitnictvi-farmacie-pojistovnictvi.html [access: 28.05.2017].

2 Referring to Deloitte Corporate Governance Centrum, in 2012, the share of top managers in the age over 40 was more than $86 \%$. Once again, the difference in questionnaire should be based mostly on the range of respondents (HR specialist are usually much younger than directors). See: http://cfoworld.cz/trendy/prumerny-cesky-manazer-se-narodil-v-roce-1962-a-letos-oslavi-padesatku-1494 [access: 28.05.2017].
}

\author{
Diversity \\ Management \\ in the Czech \\ Republic as an \\ Answer to \\ Demographic \\ Changes
}




\section{IJSR}

6

\section{Graph 1.}

Sex of respondents (\%)

\section{Graph 2.}

Age of respondents $(\%)$

\section{Graph 3.}

Position of respondents in the company $(\%)$

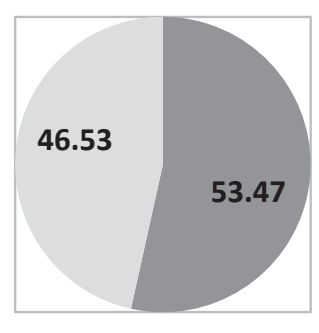

Male Female

Graph 1.
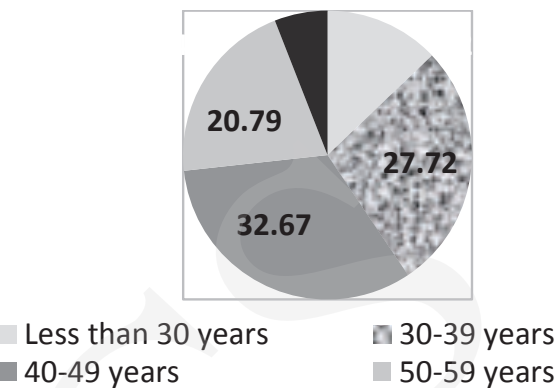

Graph 2.

Source: Own research in frames of the international project entitled "Diversity Management in the V4 Countries as an Answer to Demographic Changes".

Most of the respondents were HR specialists and owners/co-owners of enterprises (37.62\% and $75 \%$ in total). On the contrary, only approximately $15 \%$ were directors (HR or PR directors) or (vice)presidents. In other words, most of the respondents (including "others" - who were not members of top management) were members of medium or lower management.

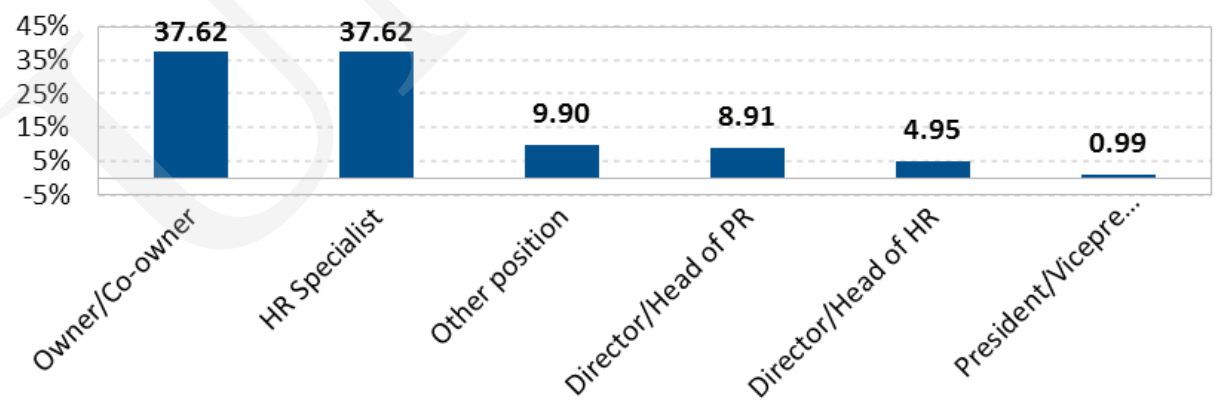

Source: As in Graph 1.

Most of the companies ( $83.17 \%$ ) were private enterprises, only $2.97 \%$ of them were NGOs and $12.87 \%$ were state-owned enterprises. From 101 respondents, only 1 was a member of a non-Czech company. In terms of the size of companies, the respondents were distributed almost evenly among small (1-49 employees, together 39.6\%, from that less than 10 employees $2.97 \%, 10-49$ employees $36.63 \%$ ), medium (50-249 employees, 30.69\%) and large (more than 250 employees, $29.7 \%$ ) enterprises. ${ }^{3}$

3 Those results are very different from national statistics, according to which almost $98 \%$ of all the enterprises are small, c. $1.7 \%$ are medium and only c. $0.4 \%$ are large enterprises. This could be caused by the fact that medium and large companies do possess more stratified management and, therefore, have - ex definition - more employees responsible for the agenda of diversity management willing and ready to answer the questionnaire. For the share of different sizes of companies, see: OECD data, https://data.oecd.org/entrepreneur/enterprises-by-business-size.htm [access: 29.05.2017]. 
An analysis of the data with the above-mentioned features of the research sample, makes it possible to conclude that the respondents' group was highly diversified, taking into account different criteria of diversity.

\subsection{7}

0.99

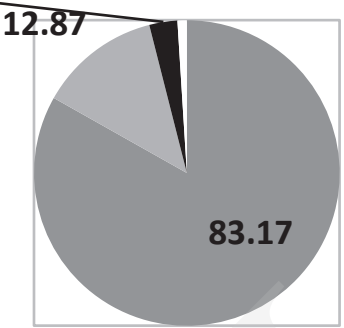

Private enterprises $\quad$ State-owned enterprises
NGO's $\square$ Other
Diversity

Management in the Czech

Republic as an

Answer to

Demographic

Changes

Graph 4.

Types of companies (\%)

Source: As in Graph 1.

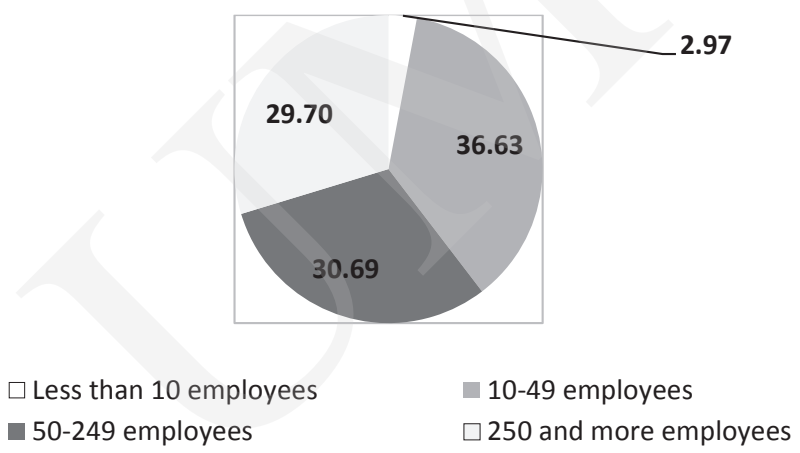

Graph 5.

Size of companies in the Czech Republic (\%)

Source: As in Graph 1.

\section{Research results}

\section{Concept of diversity management in companies}

The knowledge of diversity management (DM) among the respondents was limited - more than one-third (almost 40\%) of them had never heard about it. Only 23.76\% encountered diversity management in practice, whereas $36.63 \%$ have only heard about it. Those results are generally relevant to the question of implementing diversity management into the company's strategy. Only about $15 \%$ of companies have got explicit documents about diversity management $(8.91 \%$ have got a separate document/strategy, in $6.93 \% \mathrm{DM}$ is a part of other strategic documents of the company). Another $25.74 \%$ of enterprises incorporated DM into their code of ethics. ${ }^{4}$ Almost $60 \%$ of companies do not have any diversity management strategy and more than one-third of all of them do not even consider applying it (Anrdovicova et al., 2017).

4 Basically, this implementation is much weaker, because the codes of ethics are often just formal documents with little or no affect on the real situation in the company. 
Pobrane z czasopisma International Journal of Synergy and Research http://ijsr.journals.umcs.pl Data: 26/04/2023 15:50:41

\section{IJSR}

6

\section{Graph 6.}

Knowledge about diversity management $(\%)$

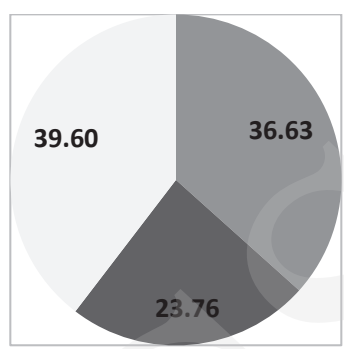

Yes, I've heard something about it $\square$ Yes, I met it in practice $\square$ No, I've never heard about it

Source: As in Graph 1.

\section{Graph 7.}

Company's diversity management strategy $(\%)$

\section{Graph 8.}

Importance of diversity management for the company $(\%)$

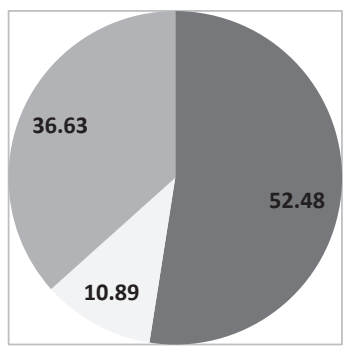

- Yes, as a separate document - Yes, as a part of code of ethics $\square$ No, we're not planning to develop

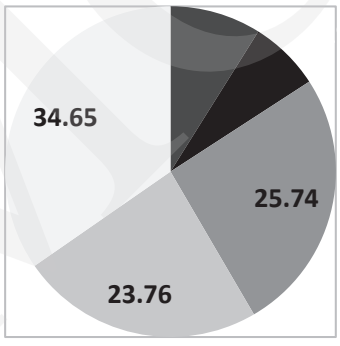

Yes, as a part of strategic documents No, but we're planning to develop
Source: As in Graph 1.

On the other hand, more than a half of the respondents (52.48\%) find diversity management important for their company and $52.47 \%$ of them think it can increase the performance of the company. The share of "I don't know" responses amounted to: $36.63 \%$ in terms of importance of DM and $14.85 \%$ in terms of its usefulness. As such, only a minority of respondents have found diversity management unimportant $(10.89 \%)$ or not useful (32.67\%).

- Yes No I don't know 
It is worth comparing the answers regarding the usefulness of DM and diverse teams for the company's performance. The share of respondents finding diverse teams useful is considerably higher than the share finding DM useful (see Table 7). An obvious explanation seems to be that the respondents find diversity important and useful, but do not think that it is important to promote it through diversity management. ${ }^{5}$

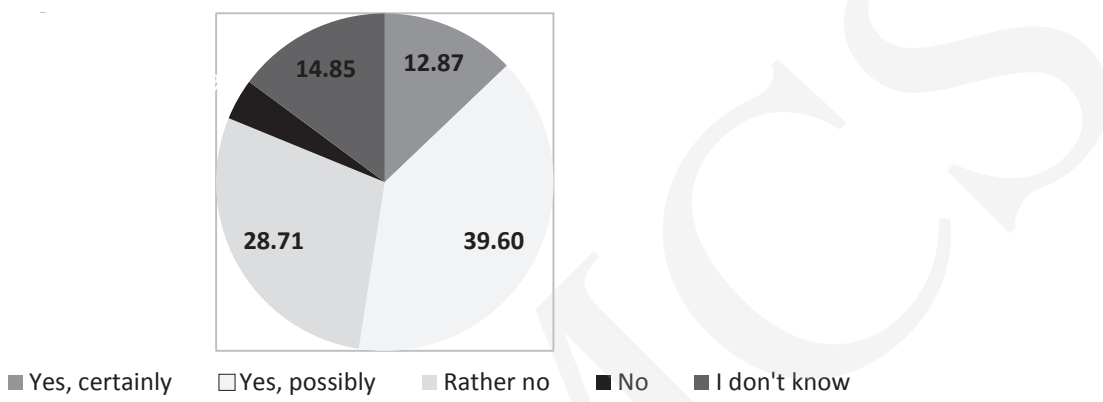

Source: As in Graph 1 .

\begin{tabular}{lcc}
\hline \multicolumn{1}{c}{ Answer } & Usefulness of DM & Usefulness of diverse team \\
\hline Yes, certainly/Strongly agree & 12.90 & 19.80 \\
\hline Yes, it's possible/Agree & 39.60 & 48.50 \\
\hline Rather no/Rather disagree & 28.70 & 26.70 \\
\hline No/Strongly disagree & 4.00 & 5.00 \\
\hline I don't know & 14.90 & - \\
\hline
\end{tabular}

Source: As in Graph 1.

The benefits delivered by diversity management for the companies can be very different. The respondents were asked to answer about every benefit in the range 1-5 ( 1 for the smallest benefit, 5 for the biggest). Based on average values, the most important benefits are: 1. Avoiding the risk of discrimination; 2. Increasing creativity; 3. Retaining best talents; 4 . Better satisfaction of employees and 5. Getting the best personnel. On the contrary, the least valued benefit was reducing costs. Coherently, the benefit of DM with the biggest share of certainty (=5) was avoiding the risk of discrimination and the one with the biggest share of mistrust $(=1)$ was reducing costs (for exact numbers, see Table 8).

5 The other (partial) explanation could be that the question 6 about usefulness of diverse team did not offer the answer "I don't know", therefore, those choosing that answer about DM would have to choose another answer now. They would probably choose the "positive" answer.
Diversity
Management in the Czech

Republic as an

Answer to

Demographic

Changes

Graph 9.

Can DM increase the performance of the company? - the Czech

Republic (\%)

Table 7.

Comparison of usefulness of diversity management and of a diverse team (\%) 
Pobrane z czasopisma International Journal of Synergy and Research http://ijsr.journals.umcs.pl

Data: 26/04/2023 15:50:41

34

\section{IJSR}

6

Table 8.

Benefits of diversity management $(\%)$

\begin{tabular}{lcccccc}
\hline \multicolumn{1}{c}{ Benefits } & $\mathbf{1}$ & $\mathbf{2}$ & $\mathbf{3}$ & $\mathbf{4}$ & $\mathbf{5}$ & Average \\
\hline Improving the image of the company & 30.69 & 7.60 & 14.94 & 19.76 & 5.47 & 2.64 \\
\hline Better motivation and performance of employees & 25.74 & 9.09 & 17.82 & 16.45 & 7.16 & 2.70 \\
\hline Better satisfaction of employees & 18.81 & 12.02 & 16.48 & 16.81 & 8.78 & 2.83 \\
\hline Increasing company profit & 23.76 & 13.48 & 17.24 & 14.66 & 6.33 & 2.61 \\
\hline Access to new markets, retaining new customers & 22.77 & 16.76 & 14.52 & 15.44 & 5.48 & 2.56 \\
\hline Getting the best personnel & 15.84 & 14.52 & 16.07 & 16.93 & 7.98 & 2.82 \\
\hline Retaining the best talents & 16.83 & 9.19 & 18.72 & 18.71 & 7.97 & 2.93 \\
\hline Increasing creativity and innovation & 14.85 & 9.09 & 20.23 & 15.22 & 11.11 & 3.00 \\
by building diverse teams & 13.86 & 9.04 & 14.35 & 18.10 & 14.73 & 3.18 \\
\hline To avoid any risk of discrimination in the company & 24.75 & 14.69 & 20.85 & 11.53 & 3.72 & 2.47 \\
\hline Increasing client loyalty & 35.64 & 16.27 & 14.16 & 10.72 & 4.62 & 2.25 \\
\hline Reduced costs & 61.39 & 5.71 & 9.70 & 1.65 & 13.44 & 2.03 \\
\hline No benefits & & & & & & \\
\hline
\end{tabular}

Source: As in Graph 1.

\section{Workforce changes}

The last part of the research dealt with the potential changes of workforce and the perception of needs, values and motivations of specific groups of employees by the management, as well as with the problems of inequality and discrimination.

One of the questions concerned the expectations about the changes of the labour market in the next five years. The answer is that the respondents are mostly expecting the increasing share of foreigners $(66.34 \%)$ and people of the age groups of $40-49$ years $(50.50 \%)$ and over 50 years $(47.52 \%)$ on the labour market, the least expected group to increase are men $(21.78 \%)$. An expected decrease is mostly associated with the groups of people aged up to 30 years $(20.79 \%)$ and over 50 years $(17.8 \%)$, the least expected groups to decrease their share in the labour market are foreigners $(2.97 \%)^{6}$ and men $(5.94 \%)$. The most stable groups on the labour market in the future are consequently expected to be men $(63.37 \%)$, women (49.50\%) and disabled people (37.62\%) (Anrdovicova et al., 2017).

The other issue dealt with the problem of workplace motivation. One of the questions asked to the groups of employees was about their motivation level (see Table 10). The number of respondents answering every category was not the same, as it ranged between 60 and 64. Regarding those answers, the most motivated groups were older employees (aged 41-49: 65.63\%, and those over 50: 54.69\%) and men (50\%), whereas, young employees $(22.22 \%)$ and disabled people $(11.48 \%)$ were perceived as the least motivated groups. Employees up to 30 years (53.97\%) and those aged 31-39 (42.86\%), as well as women (45\%) were perceived as averagely motivated. The highest degree of uncertainty about motivation refers to the group of disabled people.

6 The numbers regarding the expectations of the foreigners share can, however, be partly explained by the temporary mood in the society following the refugees crisis. 
The respondents were asked about motivation, especially about specific instruments to motivate various groups. The number of answers to every instrument varied from 50 to 82 and their results are presented in Table 11. The dominant motivational factors are very different in those groups. Regarding the age, they are: Base salary for the group up to 30 years of age (40.24\%), non-monetary incentives for the group 31-39 years

\begin{tabular}{lcccc}
\hline \multicolumn{1}{c}{ Group } & Increase & Remains & Decrease & I don't know \\
\hline Women & 29.70 & 49.50 & 11.88 & 8.91 \\
\hline Men & 21.78 & 63.37 & 5.94 & 8.91 \\
\hline Age up to 30 & 37.62 & 29.70 & 20.79 & 11.88 \\
\hline Age 31-39 & 44.55 & 34.65 & 8.91 & 11.88 \\
\hline Age 40-49 & 50.50 & 27.72 & 6.93 & 14.85 \\
\hline Age over 50 & 47.52 & 18.81 & 17.82 & 15.84 \\
\hline Disabled & 31.68 & 37.62 & 9.90 & 20.79 \\
\hline Foreigners & 66.34 & 9.90 & 2.97 & 20.79 \\
\hline
\end{tabular}

Source: As in Graph 1.

\begin{tabular}{lcccc}
\hline \multicolumn{1}{c}{ Group } & Poor & Average & Strong & I don't know \\
\hline Age up to 30 & 22.22 & 53.97 & 11.11 & 12.70 \\
\hline Age 31-39 & 4.76 & 42.86 & 44.44 & 7.94 \\
\hline Age 40-49 & 9.38 & 18.75 & 65.63 & 6.25 \\
\hline Age over 50 & 7.81 & 29.69 & 54.69 & 7.81 \\
\hline Women & 6.67 & 45.00 & 33.33 & 15.00 \\
\hline Men & 1.67 & 35.00 & 50.00 & 13.33 \\
\hline Disabled & 11.48 & 31.15 & 24.59 & 32.79 \\
\hline
\end{tabular}

Source: As in Graph 1.

of age (20\%), stability and security of employment for employees aged 50 years or more $(27.40 \%)$. In the age group $40-49$ years, there are three, almost equally important motivators (base salary: 20.73\%; bonus and material prize: $20.55 \%$; self-reliance: $20.51 \%$ ). For men, the decisive factor is participation in management $(37.88 \%$, only $12.12 \%$ for women ${ }^{7}$ ), whereas for women, it is the sense of influence on the life of local community (34.85\%, while for the men it is $22.73 \%$ ). For disabled people, the best motivational factor is (non-surprisingly) feedback.

From the point of view of the effectiveness of motivational factors on specific groups, the base salary, bonuses, employee training and non-monetary incentives are seen as the most motivating factors for the youngest group of employees. As for women, the stability

\section{Diversity \\ Management in the Czech}

Republic as an

Answer to

Demographic

Changes

Table 9.

Expectations about workforce changes on the labour market $(\%)$
Table 10.

Level of motivation of specific groups of employees $(\%)$

7 Most probably because of the already mentioned low penetration of women in the top management (see above). 


\section{IJSR}

6

of employment, sense of influence on the life of local community, solutions to work-life balance and good atmosphere at work motivate them most, while self-reliance, participation in management and promotions are working as best motivation factors for men. Feedback is seen as the best instrument for the age group of 40-49 years (Anrdovicova et al., 2017).

Table 11.

Motivation factors for specific groups of employees $(\%)$

\section{Graph 10.}

Differences in motivation level connected with age $(\%)$

\section{Graph 11.}

Differences in motivation level connected with gender $(\%)$

\begin{tabular}{lccccccc}
\hline \multicolumn{1}{c}{ Motivator } & Age up to 30 & Age 31-39 & Age 40-49 & Age over 50 & Women & Men & Disabled \\
\hline Base salary & 40.24 & 3.66 & 20.73 & 15.85 & 7.32 & 0.00 & 12.20 \\
\hline Bonus and material prize & 21.92 & 16.44 & 20.55 & 17.81 & 13.70 & 4.11 & 5.48 \\
\hline $\begin{array}{l}\text { The stability and security of } \\
\text { employment }\end{array}$ & 8.22 & 12.33 & 8.22 & 27.40 & 28.77 & 8.22 & 6.85 \\
\hline \begin{tabular}{l} 
Self-reliance \\
\hline Participation in management
\end{tabular} & 7.41 & 10.26 & 20.51 & 19.23 & 14.10 & 24.36 & 5.13 \\
\hline $\begin{array}{l}\text { The sense of influence on the life } \\
\text { of the local community }\end{array}$ & 9.09 & 10.61 & 12.12 & 19.70 & 12.12 & 37.88 & 0.00 \\
\hline $\begin{array}{l}\text { Promotion to another post and/ } \\
\text { or professional development }\end{array}$ & 15.00 & 16.67 & 11.67 & 6.67 & 20.00 & 25.00 & 5.00 \\
\hline \begin{tabular}{l} 
Feedback (praise and criticism) \\
\hline 10.61
\end{tabular} & 10.61 & 16.67 & 15.15 & 21.21 & 10.61 & 15.15 \\
\hline Employee training & 24.59 & 13.11 & 14.75 & 14.75 & 11.48 & 14.75 & 6.56 \\
\hline \begin{tabular}{l} 
Solutions to work life-balance \\
\hline 12.70
\end{tabular} & 11.11 & 19.05 & 11.11 & 30.16 & 9.52 & 6.35 \\
\hline $\begin{array}{l}\text { Good atmosphere at work } \\
\text { Non-monetary incentives (car, }\end{array}$ & 12.33 & 9.59 & 6.85 & 16.44 & 31.51 & 13.70 & 9.59 \\
\hline laptop, insurance, tickets, etc.) & 22.00 & 20.00 & 16.00 & 6.00 & 10.00 & 18.00 & 8.00 \\
\hline
\end{tabular}

Source: As in Graph 1.

Another set of questions concerned the feeling of differences in motivation based on gender and age. The results were quite similar: approximately $60 \%$ of respondents noticed some differences. $63.37 \%$ of them identified age, whereas gender was indicated by $58.42 \%$. Polish researches - Rakowska and Sitko-Lutek (2015) - have also written about the characteristics of different employee groups, diversified in terms of age, gender or profession, creating a positive outlook in terms of offering more ways of utilising human capital, which, in turn, leads to an increase in the level of competitiveness of an enterprise.
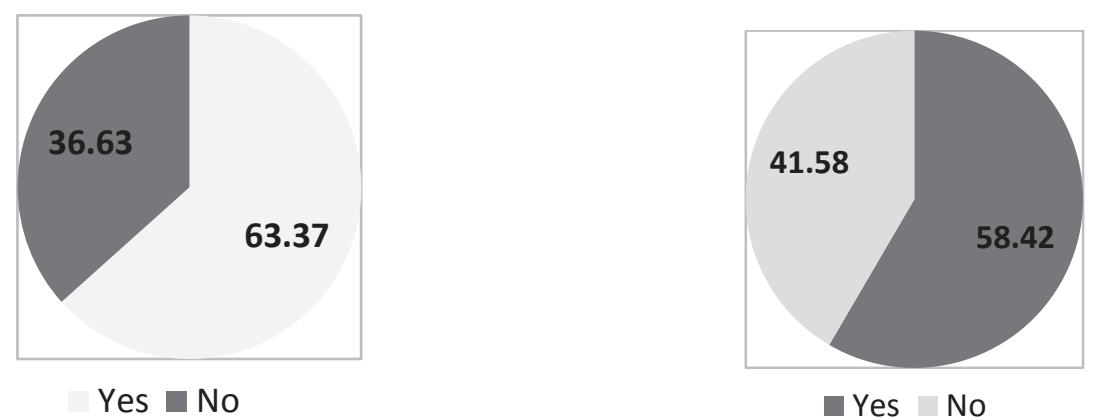

Source: As in Graph 1. 
Another question was connected with groups of employees with valuable ideas, competences and opinions for companies. The respondents were asked to choose the groups which are most valuable from this point of view. ${ }^{8}$ With reference to Graph 12 , those groups are: 1. Employees in the age of 40-49 years $(60.40 \%) ; 2$. Employees in the age of 30-39 years $(43.56 \%)$ and 3. Men $(30.69 \%) .{ }^{9}$ On the contrary, the least "successful" in this parameter were disabled employees. ${ }^{10}$

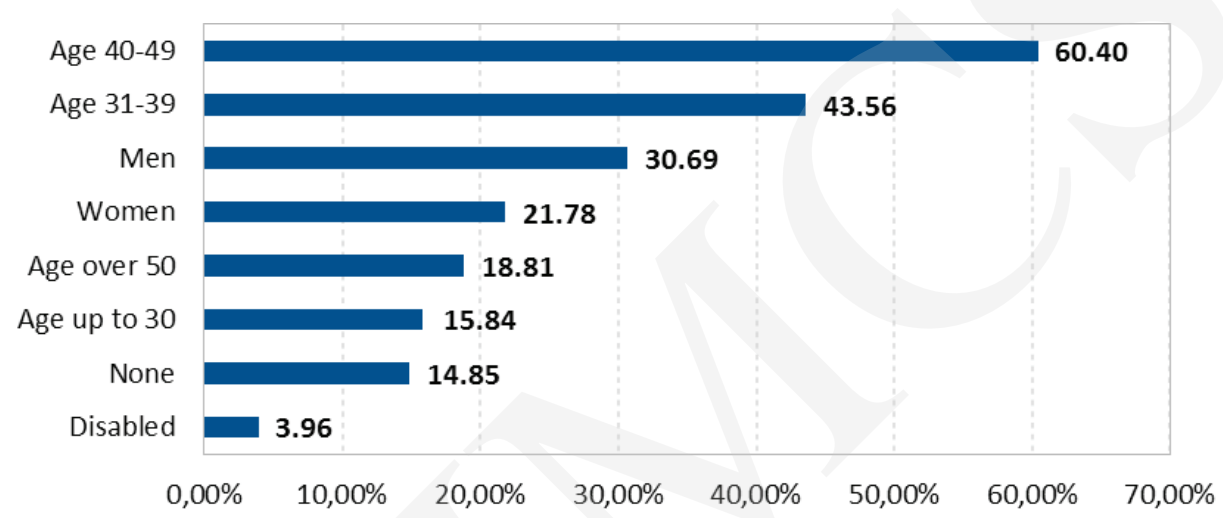

Source: As in Graph 1.

Workplace discrimination is yet another important issue, which diversity management aims to tackle. Respondents were asked about the most widespread types of discrimination. ${ }^{11}$ Graph 13 indicates, that age is seen as the biggest reason for discrimination $(61.39 \%)$, followed by gender (43.56\%) and education (36.63\%). On the other hand, belief or sexual orientation are rarely seen as dominant factors. However, different forms of discrimination can affect specific groups differently. Therefore, respondents were asked, which groups of employees are mostly discriminated in various areas (see Table 12). Recruitment and layoffs were seen as the biggest factors of discrimination for employees older than 49 years, while determining remuneration and access to training discriminated disabled people at the most. For women, access to promotion and work-life balance were found as the most discriminating.

\footnotetext{
8 With a maximum of three answers to choose, therefore, the percentages in Graph 12 are the share of 101 total respondents (and their sum is over $100 \%$ ).

9 Surprising is the small percentage of the group in the age of 50 years and more. Those employees should be, ex definitione, the most experienced and their ideas generally most valuable. The explanation seems to be in the technology development, which, in case of this group, is difficult to keep up with.

10 Disabled people can, of course, be very useful in bringing new ideas or opinions, just because of their different point of view. Such a low amount of answers seems to indicate, that the enterprises in the Czech Republic are still not used to dealing with those employees and often perceive them as "inferior"

11 With a maximum of three answers to choose, therefore, the percentages in Graph 13 are the share of 101 total respondents (and their sum is over $100 \%$ ).
}

\section{Diversity \\ Management in the Czech \\ Republic as an \\ Answer to \\ Demographic \\ Changes}

Graph 12.

Groups of empoyees with valuable competencies, opinions and ideas (\%) 
Pobrane z czasopisma International Journal of Synergy and Research http://ijsr.journals.umcs.pl Data: 26/04/2023 15:50:41

38

\section{IJSR}

6

\section{Graph 13.}

Reasons

for discrimination

of employees (\%)

Table 12.

Areas of discrimination of employees (\%)
Graph 14.

Specifying employees' special needs with regard to particular aspects (\%)

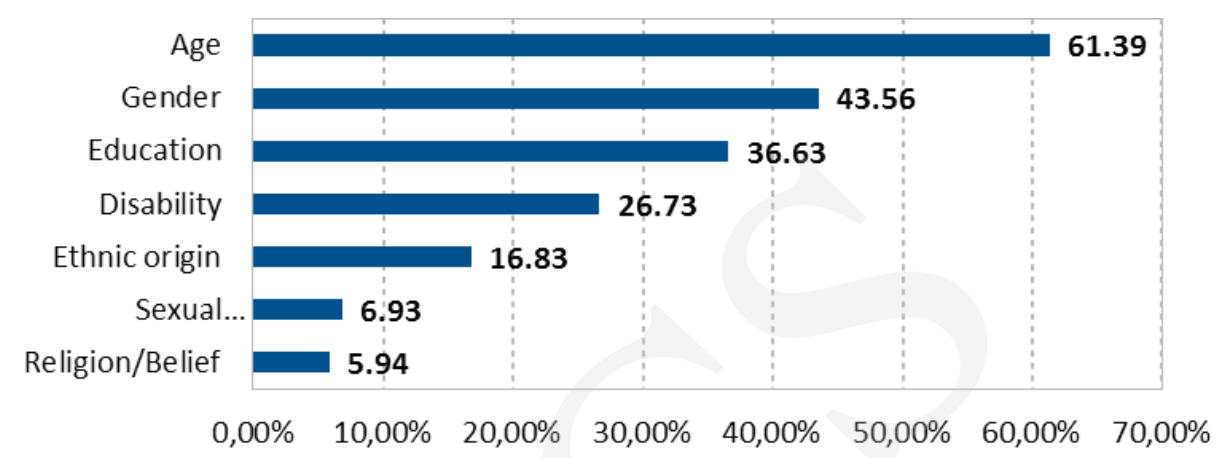

Source: As in Graph 1.

\begin{tabular}{lrrcccc}
\hline \multicolumn{1}{c}{ Group } & Recruitment & Layoffs & $\begin{array}{c}\text { Determining } \\
\text { remuneration }\end{array}$ & $\begin{array}{c}\text { Access } \\
\text { to training }\end{array}$ & $\begin{array}{c}\text { Access to } \\
\text { promotion }\end{array}$ & $\begin{array}{c}\text { Work-life } \\
\text { balance }\end{array}$ \\
\hline Age up to 30 & 21.78 & 12.87 & 8.91 & 4.95 & 9.90 & 9.90 \\
\hline Age 31-49 & 0.00 & 1.98 & 3.96 & 2.97 & 3.96 & 3.96 \\
\hline Age over 50 & 36.63 & 37.62 & 10.89 & 16.83 & 16.83 & 12.87 \\
\hline Disabled & 27.72 & 35.64 & 38.61 & 50.50 & 30.69 & 28.71 \\
\hline Women & 12.87 & 11.88 & 35.64 & 20.79 & 33.66 & 36.63 \\
\hline Men & 0.99 & 0.00 & 0.99 & 3.96 & 4.95 & 7.92 \\
\hline
\end{tabular}

Source: As in Graph 1.

The study also analysed the issues of the specific needs of employee groups whether they specify their specific needs related to their age, gender etc. With reference to Graph $14,{ }^{12}$ the special needs are mostly related to age $(64.36 \%)$, work-life balance $(35.64 \%)$ and gender (34.65\%). Among the least commonly indicated reasons were beliefs $(4.95 \%)$ and origin $(0 \%)$.

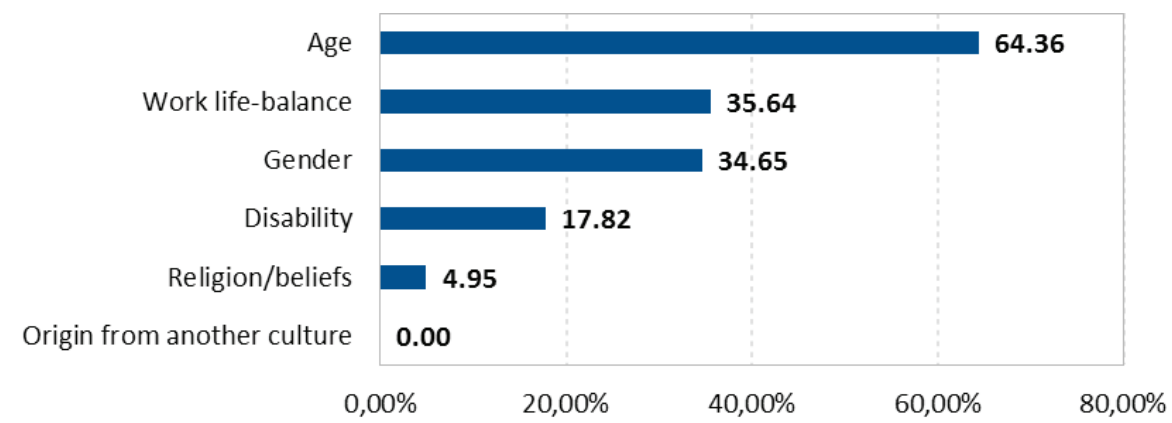

Source: As in Graph 1.

12 With the possibility of multiple answers to choose, the percentages in Graph 14 are the share of 101 total respondents (and their sum is over 100\%). 


\section{Summary and conclusion}

The population diversity and labour forces are both becoming more salient topics in the Czech Republic. There is a high share of women, whereas the share of older people is still increasing. Gender and age diversity are the most significant elements of diversity, but it is also possible that other elements of diversity such as ethnic or mental and physical abilities will become more important in the future.

The research study was conducted on a limited, but relevant set of respondents, who offered their insight. The analysis of the data collected made it possible to draw conclusions from empirical studies and formulate fundamental postulates in relation to the examined economic reality, in the field of diversity management and demographic changes. First of all, knowledge and practice of diversity management is not very widespread in the Czech Republic. Secondly, most of the respondents recognize differences in motivation factors for specific groups of employees. The majority of respondents notice the values and benefits of different groups of employees, as well as their specific needs. The majority of respondents know that specific groups can be objects of various types of discrimination. The above-mentioned results (with a relatively low importance and knowledge of diversity management and its application in the Czech Republic) correlate with the answers to the last question analysed, which was: "Would you like to take part in the 'Diversity Management' course?" Only approximately $1 / 3$ of the respondents would be interested (9.90\% - "yes", 27.72\% - "rather yes"), whereas more than a half expressed non-interest in such a course and about $8.91 \%$ did not answer the question.
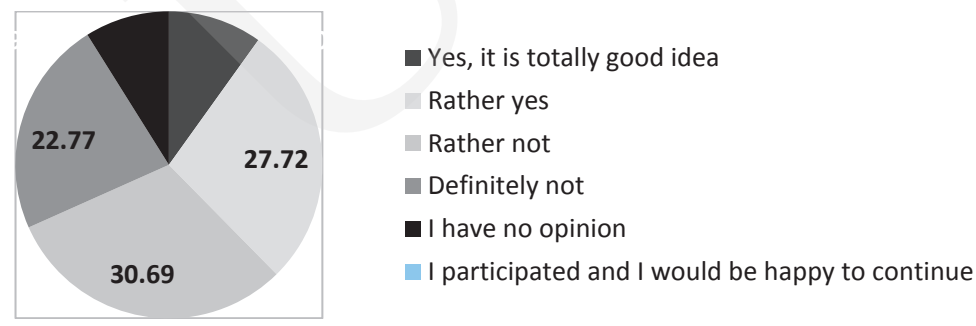

Source: As in Graph 1.

In conclusion, while most of the managers/respondents do understand the values and benefits brought by diversity, they do not see (or are even not aware of) diversity management as an effective instrument to promote (or work with) it. The potential for diversity management studies and programs seems to be relatively large in the Czech Republic.

When pondering changes in society, in the environment of an organisation and in the work place, it becomes clear that diversity has and will continue to play a crucial role in the competitive and organisational success. Therefore, irrespectively of whether one views diversity as a social issue, pertaining to the workplace or the consumer market, demographic changes should not be ignored. The character of the society and human resources are both changing, and the conducted analysis shows that in the future they will change significantly. Vis-à-vis the challenges faced by organisations, managing diversity ought to become an important issue for managers - from observing diversity to planning

\author{
Diversity \\ Management \\ in the Czech \\ Republic as an \\ Answer to \\ Demographic \\ Changes
}

Graph 15.

Interest in attending the "Diversity

Management” course

(\%) 
IJSR

6 to manage it effectively as well as employing diversified human resources - as diversity is simply a fact. Such an approach serves as a gauge of the quality of management. For instance, in the United States, over the last 20 years, diversity and integration have both become important elements of the concept of managing organisations. According to SHRM data, $55 \%$ of large companies in the USA are promoters of diversity, whereas $42 \%$ of diversity programmes are supported by CEOs, the highest levels of management and Human Resources Officers (HRO).

Importantly, this does require a proper understanding of the essence of diversity and social integration. Fundamentally, it should be assumed that diversity management is a path towards constantly discovering people, their input and value, which may prove beneficial for both organisations and societies. Therefore, diversity should be viewed as reality, not as a problem. It, therefore, seems that in the $21^{\text {st }}$ century, success of every organisations will depend upon whether they will be able to manage diversity more effectively than they did in the past. Organisation, which will make diversity management part of their business strategy will be the winner.

\section{References}

Anrdovicova, J., Florek, I., Gross-Gołacka, E., Laki, I., Markova, J., Sitek, M., Sitek, P., Slavicek, J., Uhlerova, M. (2017). Diversity Management in the V4 Countries as an Answer for Demographic Changes. Final Report, WSGE, Józefów.

Egan, M.L., Bendick, M. (2008). Combining Multicultural Management and Diversity into One Course on Cultural Competence. Academy of Management Learning and Education, vol. 7, no. 3, pp. 387-393.

Eger, L. (2012). Diversity Management. Comparison, the Best Practices of Visegrad Countries, Nava, Plzeň.

Elexowa, G. (2011). Human Resources Development under the Conditions of the Global Crisis. E $+M$ Ekonomie a Management, vol. 14, no. 3, pp. 46-55.

European Commission, (2017). European Semester Thematic Factsheet Active Labour Market. Retrieved November 22, 2017 from: https:/ec.europa.eu/info/sites/info/files/file_import/ european-semester_thematic-factsheet_active-labour-market-policies_en.pdf

European Commission. 2015. Demography Report - 2015 edition. Retrieved November 22, 2017 from: http:/ec.europa.eu/Eurostat

Gross-Gołacka, E. (2018). Zarządzanie różnorodnościa. W kierunku zróżnicowanych zasobów ludzkich w organizacji, Difin, Warszawa.

Gross-Gołacka, E. (2016). Rola koncepcji zarządzania różnorodnością w doskonaleniu organizacji. Problemy Jakości, nr 4.

https://www.czso.cz [access: 22.11.2017].

http://cfoworld.cz/trendy/prumerny-cesky-manazer-se-narodil-v-roce-1962-a-letos-oslavipadesatku-1494 [access: 28.05.2017].

Marková, J. (2017). Zaměstnanost v ČR v rámciprogramovéhoobdobí 2014-2020 a strategie Evropa 2020 In: J. Dušek a kol. Nezaměstnanost a determinanty trhupráce v podmínkáchmoderníchevropských ekonomik, Vysokáškola evropských a regionálních studií, České Budějovice, pp. 12-25.

Loden, M., Rosener, J.B. (1991). Workforce America! Managing Employee Diversity as a Vital Resource, Business One Irwin. Illinois

Mor Barak, M.E. (2011). Managing Diversity. Toward a Globally Inclusive Workplace, Sage Publications, Thousand Oaks. CA 
OECD data. Retrieved May 29, 2017 from: https://data.oecd.org/entrepreneur/enterprises-bybusiness-size.htm

Özbilgin, M.F., Tatli, A. (2008). Global Diversity Management: An Evidence-Based Approach, Palgrave Macmillan, Basingstoke-New York.

Rakowska A. (2014). Różnorodność zasobów ludzkich - stan badań i wyzwania, Prace naukowe Uniwersytetu Ekonomicznego we Wrocławiu nr 349, UE, Wrocław, pp. 351-360.

Rakowska, A., Sitko-Lutek, A. (2015). Zarządzanie zróżnicowanym zasobami ludzkimi a koncepcja i modele. In: A. Jaki, M. Kowalik (Eds.), Współczesne oblicza i dylematy restrukturyzacji, UE, Kraków, pp. 41-53.

The Share of Women in Top Management, (2014). Deloitte Corporate Governance Centrum. Retrieved May 28, 2017 from: https:/www2.deloitte.com/cz/cs/pages/about-deloitte/ articles/cze-zeny-ve-vedeni-firem-zdravitnictvi-farmacie-pojistovnictvi.html

Thomas, R.R. Jr. (1991). Beyond Race and Gender. Unleashing the Power of Your Total Work Force by Managing Diversity, AMACOM, New York.

Thomas, R.R. Jr. (1999). Building a House for Diversity, AMACOM, New York. 
